DE

DE GRUYTER

OPEN

G
Journal of Intercultural Management

Vol. 7, No. 3, September 2015, pp. 5-14

DOI 10.1515/joim-2015-0018

Jan Żukowskis ${ }^{1}$

Aleksandras Stulginskis University

Paula Pypłacz ${ }^{2}$

Czestochowa University of Technology

Janusz Sasak ${ }^{3}$

Institute of Public Affairs of the Jagiellonian University

\title{
Shaping Small and Medium-Sized Enterprises' Business Environment
}

Abstract: Modern enterprises appear to be more and more focused on their intangible assets, among which the intellectual capital plays an important role. One of its components - relational capital - is an essential value of an organization as it helps build long-lasting relations between the company and its stakeholders. This, in turn, leads to a business' competitive advantage. With the help of a research conducted, this study attempts to assess the relations between small and medium-sized enterprises (SMEs) and their business environment institutions.

Key words: small and medium sized enterprises, intellectual capital, relational capital

\section{Introduction}

The condition necessary to keep a current enterprise functioning effectively, is to ensure constant improvement and adjustment to ongoing market changes. For there is no enterprise that can operate in isolation from an environment and entities

\footnotetext{
${ }^{1}$ jan.zukovski@asu.lt

2paula@zim.pcz.pl

3 janusz.sasak@uj.edu.pl
} 
functioning in it. Avoiding threats and seizing opportunities is largely dependent on the ability to analyze the dynamic environment. Anticipating the future, and especially determining future business, technical and economical relations, is highly believed to have and important meaning for running and administrating the company. Environmental signals constitute a basis for rational planning and building the strategy. Thereby, operating becomes more creative, flexible and resistant to critical situations.

The above observations lead to a conclusion that most implemented business and managing solutions help obtain competitive advantage, but only a short-term one. Only long-term and strategic building of stable business relations between the company and its stakeholders results in maintaining the competitive advantage. Ipso facto, relational capital of the company as part of widely understood intellectual capital, becomes the core asset of a company and the source of its competitive advantage.

This study attempts to assess the relations between small and medium-sized enterprises with other entities in the business environment. The study presents the results of pilot research conducted in the fourth quarter of 2014 and the first quarter of 2015. The research focused mainly on the three stakeholders' groups: suppliers, customers and competitors as the three groups are considered to be the most important in the process of creating business relations between the company and the environment. The conducted pilot research will be widened with further aspects of business relations and different groups of stakeholders.

\section{The concept of relational capital}

The fact that there has been an enormous development of technology and automation of production processes in knowledge-based economy, gives intangible resources, especially intellectual capital a higher meaning. It constitutes a part of company's total value and is at the same time a difference between market value and the book value of the company [Pietruszka-Ortyl 2004, p. 12]. The intellectual capital is treated also as a source of financing company's intangible resources that contribute to generating future benefits which influence the process of company's value creating [Dobija 2003, p. 10].

In literature intellectual capital is defined in various ways. It is perceived like knowledge that consists of many different factors like: appropriately chosen technology, employees' experience and skills, processes and information about suppliers and customers [Stewart 1997, p. 11]. One of the most frequently cited definitions, created by Leif Edvinsson, states that the entirety of intellectual capital of an entity consists of: human capital, structural capital - relational internal, relational external and organizational capital [Edvinsson, Malone 2008, p. 39]. Intellectual capital is definitely influenced by relations (appropriately shaped) occurring among the three components. 
Relational capital, which refers to relational resources founded on the ground of the potential accumulated in an entity, which means employees' skills [BąkowskaMorawska 2008, p. 115] and relations between a company and other entities, is a part of intellectual capital.

Relational capital covers knowing competition's strategy and external conditioning including country's economic stance and the politics. Relations are established both with internal stakeholders like the owners, management, employees, unions and external stakeholders like suppliers, clients, competitors, financial institutions, local and state administration and local society. As can be seen, there are many different relations to be established and taken care of. It is essential to involve the whole team in building advantageous relations between the entity and its stakeholders, as it favors gaining benefits by both parties. Relational capital can be treated not only statically as a resource related with interpersonal relations but should also be seen from a dynamic perspective, as an ability to create and maintain stable relations founded on trust and cooperation. Such an approach together with effective company-stakeholders relations management can contribute to gaining numerous benefits like [Chomiak-Orsa 2012, p. 52]:

- increasing the probability to obtain an approval for operating and changes implemented;

- establishing good reputation and a positive market image;

- obtaining and creating useful resources (also unique ones).

\section{Assessment of SMEs business environment relationships}

The pilot survey was carried out among 142 SMEs sector entities of different trades. There were 91 small enterprise participants (including micro-enterprises) and 51 medium-sized company participants. The survey was conducted in the fourth quarter of 2014 and the first quarter of 2015 using electronic forms. An in-depth research group was randomly chosen from among the respondents who completed electronic questionnaires. The research took a form of questionnairebased interviews made by pollsters.

The respondents are representatives of companies running their businesses in Silesia and Opole Province. They are both management staff members (67\% of small and $21 \%$ of medium-sized companies) and workers (24 small company respondents and 30 medium-sized companies respondents). Management staff prevalence is a result of the number of small enterprises, where an owner is a manager at the same time. The enterprises being studied mostly do business at the local or regional market whereas international range concerns only 3 small entities and 10 mediumsized ones.

It is an intellectual capital and its different aspects that are paid attention to in the survey. Components of intellectual capital consist of human capital, structural 
capital and relational capital. The latter one is shaped by relationships established with customers, suppliers, distributors and other stakeholders, mainly being close to. The research unambiguously indicates that the relationships established with their stakeholders do satisfy the respondents, which is presented in graph 1 . The relations are predominately partnerships or neutral. Moreover, the relations are claimed by management staff respondents to be built on purpose $(79 \%$ of answers given by small organizations participants and $86 \%$ of answers given by mediumsized organizations participants). The situation looks similar among the workers - 54\% of answers given by small entities and $60 \%$ answers given by medium-sized entities.

\section{Graph 1. Company - stakeholders (suppliers, customers, competitors) relationships assessment}

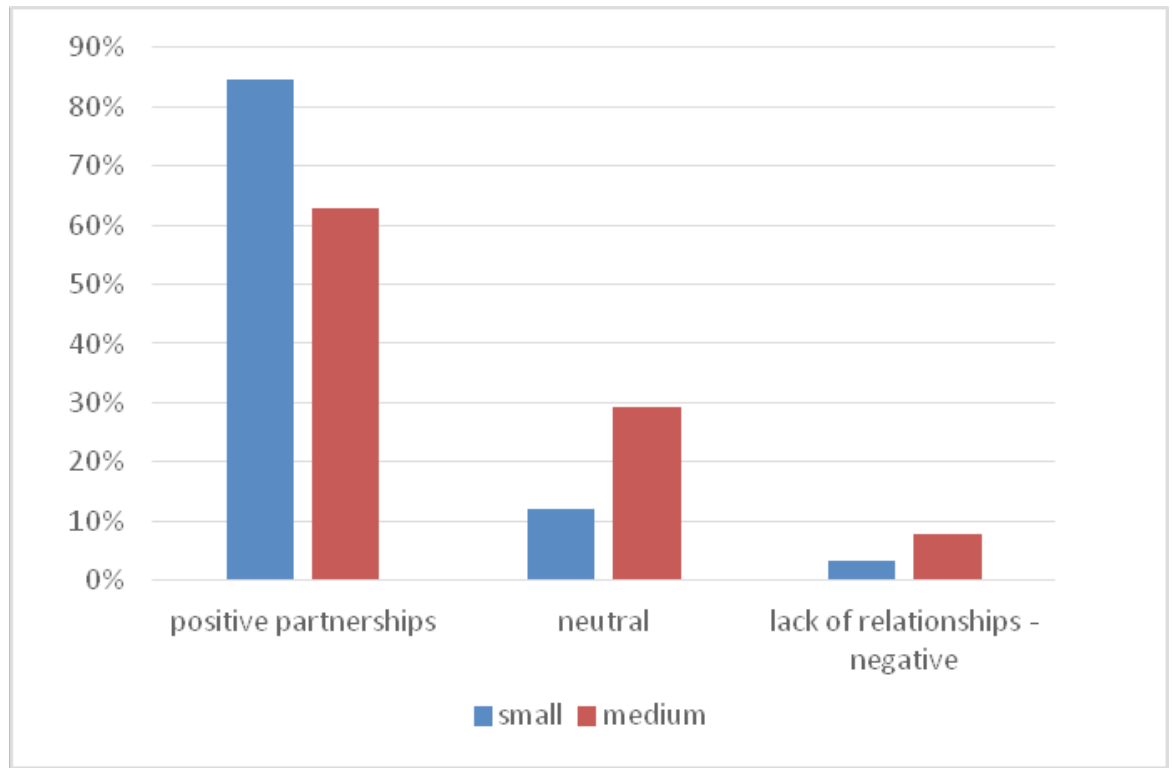

Source: own study based on the research.

Customer relationships appear to be assessed best both among small companies $(76 \%)$ and medium-size ones (46\%). The weakest relations are established between small enterprises and economic organizations such as clusters, incubators and transfer centers (68\% of answers), whereas in medium-sized enterprises centers of expertise relations are found the poorest (65\% of answers). Graph 2 presents all answers given by the respondents. SMEs are not convinced enough to establish solid relationships with institutions they have no straight business connections and 
which they are not dependent on. Therefore, the potential of those institutions is lost instead of being exploited.

\section{Graph 2. Company - stakeholders relationship strength}

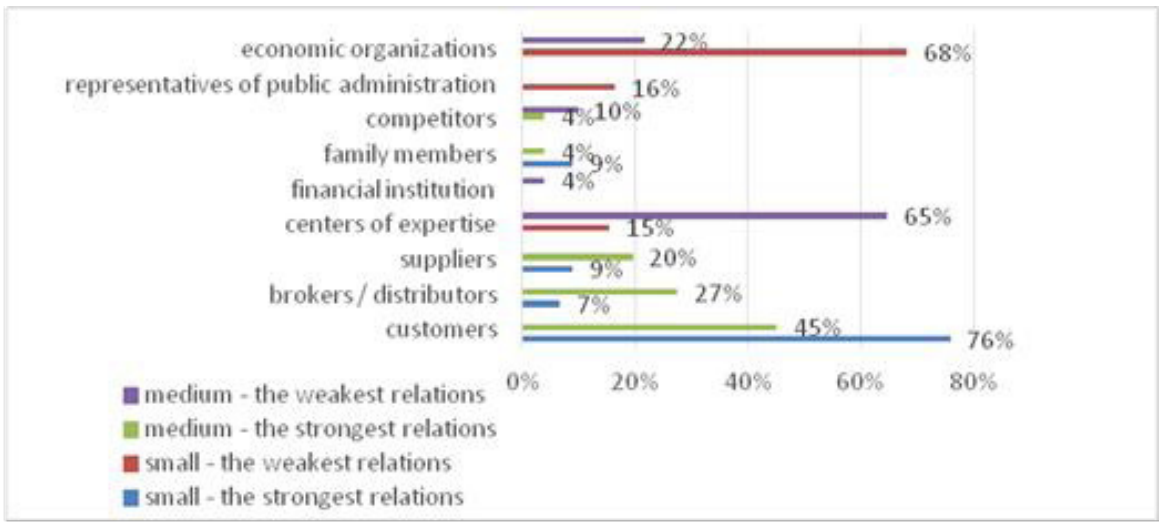

Source: own study based on the research.

Whether a company strives for positive relations with third parties or not mostly depends on possible future benefits which may be brought. While analyzing the respondents' answers it is easy to observe that small and medium-sized companies tend to show similarities. Aiming for and maintaining partnerships may be explained by the need for a company competitiveness. Both respondent groups, managers and workers, indicate three main issues saying that positive relations with suppliers, customers and competitors:

- contribute to enlarging the scope of action - 82\% of small companies and $83 \%$ of medium-sized ones

- contribute to professional action improvement - $88 \%$ of small companies and $84 \%$ of medium-sized companies

- contribute to cooperative problem solving. 


\section{Graph 3. Benefits of maintaining stakeholders relations: suppliers, customers, competitors}

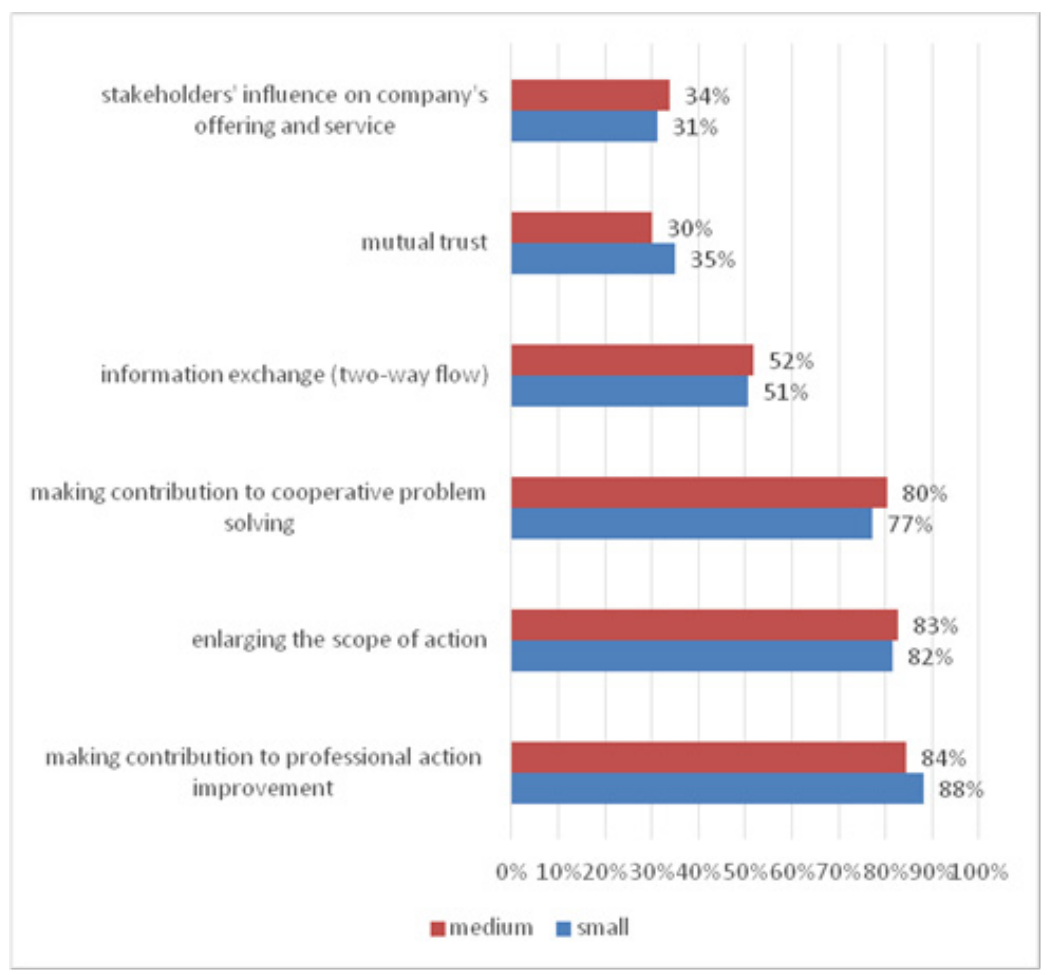

Source: own study based on the research.

As can be observed, only two first points are presented in a different order, but the disparity is almost unnoticeable. Such points like mutual trust and stakeholders' influence on company's offer were indicated least often. These aspects will be given a deeper consideration further on in the study when specific groups of stakeholder relations are examined.

Taking into account relations with suppliers, small companies' respondents mostly focus on beneficial cost-effective pricing conditions and payment dates $(63 \%)$ as well as delivery timeliness (49\%). The two aspects do matter to both sides but small entities consider them weak points as they often have to face liquidity and delivery problems. The area of developing mutual trust and safety attracts $43 \%$ of respondents. Yet, rarely is the importance of product and service innovation pointed by the respondents. The situation looks similar when medium-sized companies are being examined, as presented in graph 4. 


\section{Graph 4. Benefits of buyer-supplier relationships}

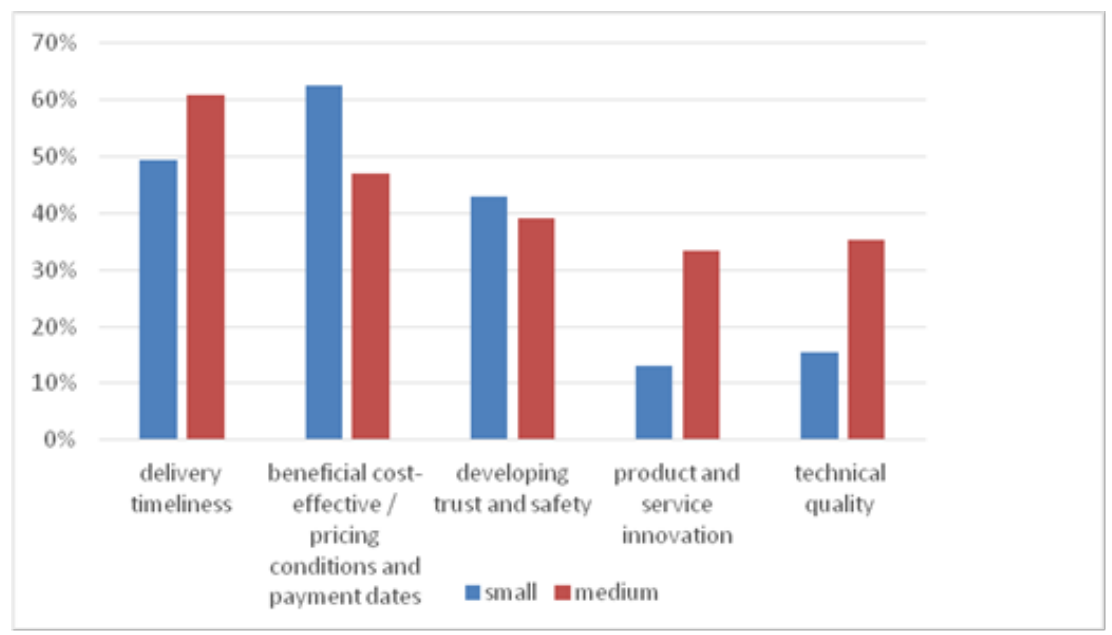

Source: own study based on the research.

When relations between a company and a competitor are taken into account, creating and maintaining their interaction are mostly being indicated. Except this aspect, there is no action observed leading towards any mutual affairs between companies and their competitors. Such an attitude is shared both in small (87\%) and medium-sized companies $(72 \%)$. The question to be answered now is therefore where they get the knowledge about their competitors from. As shown in graph 5 , intentional or even occasional market monitoring from the perspective of competition is hardly conducted. Companies tend to rely on general knowledge accessible to all units, often gained unintentionally. The research shows, on the other hand, that almost half of medium-sized companies $(47 \%)$ is aware of their competitors' strategies, strong and weak points and actions. Small entities reached a better place in this area $(74 \%)$. Yet, the knowledge concerns only selected competitors. It is therefore worth wondering whether the information is complete and reliable enough to uncover, for example, the opponent's strategies. The knowledge may turn out to be an abstract concept when it comes to reality. It is therefore easy to assume that the superficiality of relations with competitors is a result of the lack of relevant, complete knowledge. 
Graph 5. Gaining knowledge about main competitors

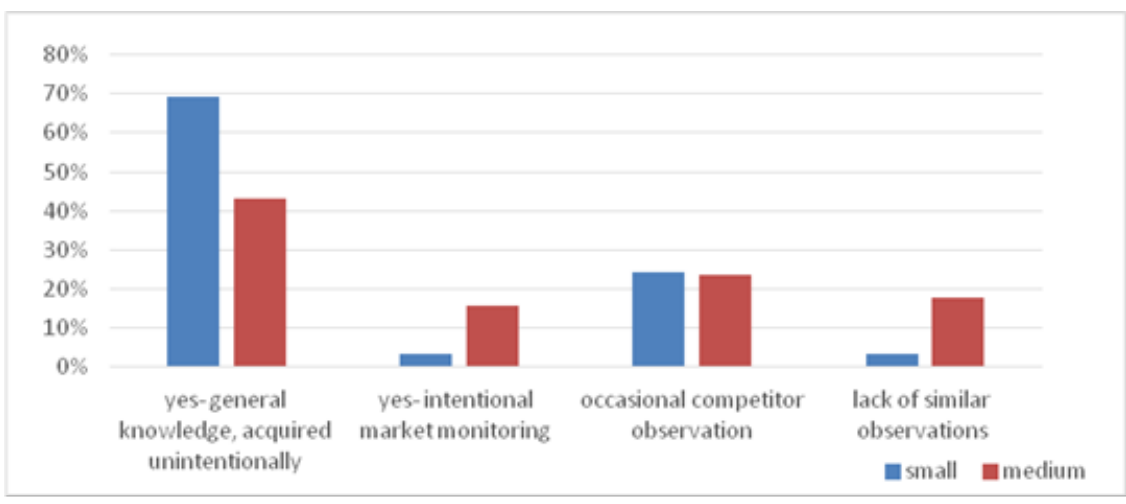

Source: own study based on the research.

The issue of customer relationship appear to be more optimistic despite the fact that it is also based on fragmentary research. Graph 6 reflects the structure and specific nature of customer relationships. The findings confirm that businesscustomer interactions are of a similar structure and characteristics both in small and medium-sized enterprises.

Business-customer relations concern:

- during, after-sales services and beneficial terms of service

- developing trust and safety correlation

- beneficial cost-effective / pricing conditions and payment dates

- order execution timeliness

- developing long-term relationships

Medium-sized companies also pay much attention to concession agreements possibilities ( $40 \%$ of answers).

\section{Graph 6. Business-customer interactions}

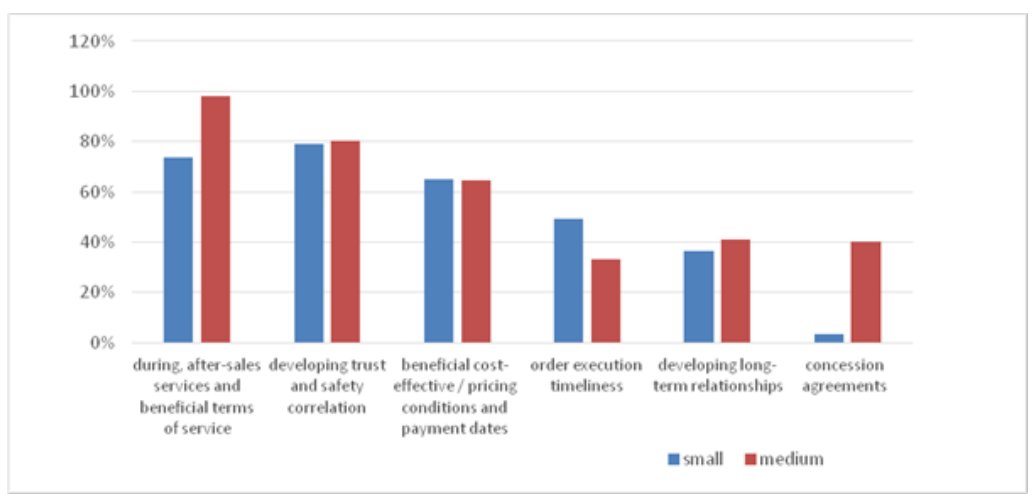

Source: own study based on the research. 
The results clearly prove that unlike the previously analyzed relations, the ones with customers appear to be strongly desired as the respondents applied to all answers.

\section{Graph 7. Customer satisfaction and loyalty}

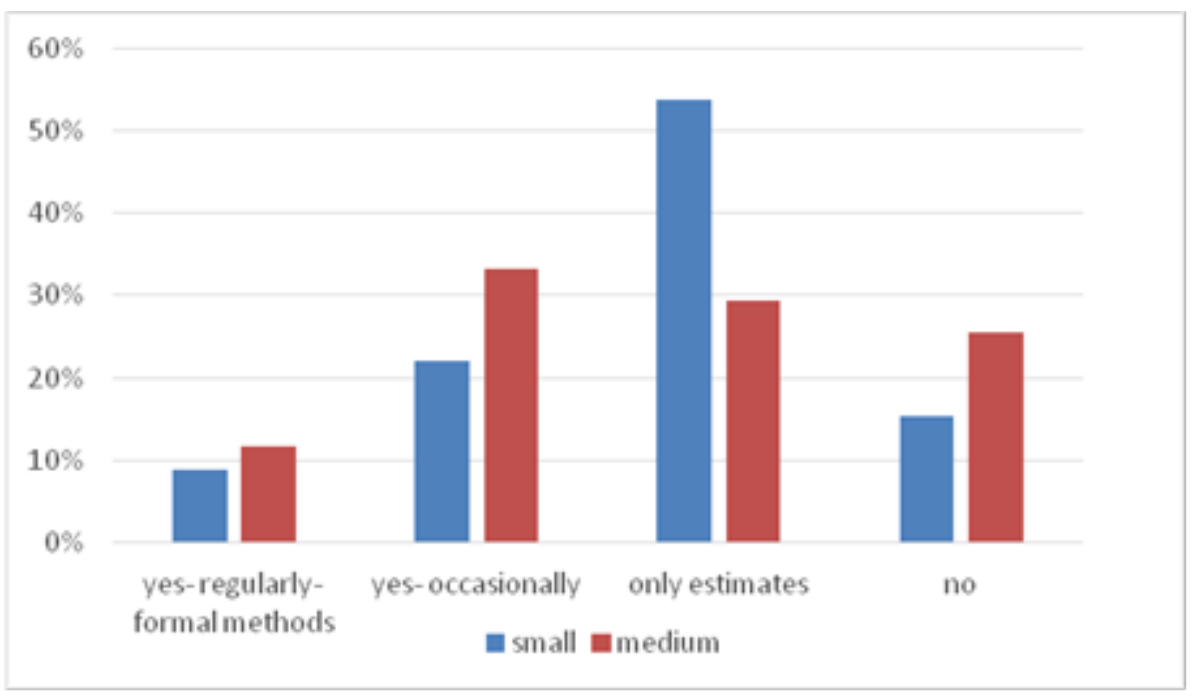

Source: own study based on the research.

Even though the loyalty level of their customers is measured low or tolerably enough, the respondents still attempt to gather some information on them (graph 7). However, these actions do not seem to be carried out respectively, which, in turn, results in misperceiving the issue of customer commitment. $12 \%$ of mediumsized companies systematically analyze customer satisfaction and loyalty using formal methods, whereas $37 \%$ of them occasionally conduct such examinations. Yet, the situation looks much worse when small companies are being considered as $54 \%$ of them only use approximate estimates in this area. Even though the pricing factor mostly influences marketing strategy, neither small organizations $(87 \%)$ nor medium-sized ones (61\%) regularly examine their customers' price sensitivity. As much as $76 \%$ of small companies and $67 \%$ of medium-sized ones follow standards in their service offering, like, for example introducing seasonal collections. $74 \%$ of small and $46 \%$ of medium-sized companies adapt their offering strategies to the knowledge and experience acquired on their own. 


\section{Summary}

Customer relations are proved to be significantly important and commonly admitted. However, the necessity to build solid relations with other stakeholders is also revealed. Such relations are important from the perspective of presenting company's uniqueness and maintaining competitive advantage. Furthermore, market volatility requires immediate response and adjusting to new situations. Not only is gathering detailed information about market and business entities important but also its thorough analysis and interpretation. According to the research carried out, SMEs sector companies tend to rely on selective data, mostly gained by accident and thus, not fully reliable.

The research also indicates that both staff groups, managers and workers, do understand the significance of maintaining the existing relationships with their stakeholders and building the new ones. However, emphasis should be placed on their quality. It is therefore necessary to build up some strategies constituting the result of both, competitiveness and cooperation between stakeholders involved in mutual business actions.

\section{Bibliography}

Bąkowska-Morawska U. (2008), Elastyczność zasobón relacyjnych [in:] R. Krupski (ed.), Elastyczność organizacji, Wyd. UE we Wrocławiu, Wrocław, p. 115.

Chomiak-Orsa I. (2012), Kapitat relacyjny stymulatorem prz̨ewagi konkurencyjnej wspótczesnnej organizacji [in:] D. Jelonek (red. naukowa), Wybrane problemy zarzadzania wiedza $i$ kapitatem intelektualnym w organizacji, Sekcja Wydawnictw Wydziału Zarządzania Politechniki Częstochowskiej, Częstochowa 2012, p. 52.

Dobija D. (2003), Pomiar i sprawozdawczość kapitatu intelektualnego przedsiębiorstwa, Wyd. Wyższej Szkoły Przedsiębiorczości i Zarządzania im. Leona Koźmińskiego, Warszawa, p. 10.

Edvinsson L., Malone M.S. (2001), Kapitat intelektualny, PWN, Warszawa.

Herman A. (2008), Kapitał intelektualny i jego liczenie, „Kwartalnik Nauk o Przedsiębiorczości”, no 3 , p. 39.

Pietruszka-Ortyl A. (2004), Proces zarzadzania kapitatem intelektualmym organizacji, „Przegląd Organizacji”, no 6, p. 12.

Stewart T.A. (1997), Intellectual Capital: The New Wealth of Organization, Nicholas Brealey, London from: M. Kunasz, Ogólny zarys koncepcji kapitału intelektualnego [in:] Kapitat ludzki w gospodarce, red D. Kopyciński, Polskie Towarzystwo Wydawnicze, Szczecin 2003, p. 11. 